\title{
Tibuana
}

Journal of applied Industrial Engineering-University of PGRI AdiBuana

DOI : https://doi.org/10.36456/tibuana.4.02.4029.131-139

p-ISSN 2622-2027

$e$-ISSN 2622-2035

\section{Applied of Balanced Scorecard (BSC) Approach with Determination and Weighting of Key Performance Indicator (KPI) for Employee Performance Measurement}

\author{
Muhammad Nushron Ali Mukhtar ${ }^{1}$, Agung Setiawan ${ }^{2}$, dan DjokoAdi Walujo ${ }^{3}$ \\ ${ }^{1,2,3}$ Industrial Enggineering Departement, Faculty of Technology \\ University Of Adi Buana Surabaya \\ Email :nushron@unipasby.ac.id
}

\begin{abstract}
The many types of production of goods in a company spearhead the progress of this company in industrial competition in Indonesia, the variety of types of products and large production capacity makes this company need a large number of employees to balance the variety and production capacity. This large number of employees creates its own problems, one of the problems is employee performance appraisal, employee performance appraisal in this company is only centered on the highest supervisor's consideration in one section. From that problem, the researcher wants to solve the problem using the Balanced Score Card (BSC) method by using the determination and weighting of Key Performance Indicators (KPI). The final result of the research conducted at PT Alam Jaya Primanusa in May 2018 the results of the following employee achievement grades and categories: Average material value: 76.65 Fair category, Operator's average value: 85.51 Good category, Average value - Selector section average: 89.79 Good category, Packer section average value: 94.98 Good category, Values in each of these sections become the basis for calculations for all injection division production, so conclusions are drawn for the final value and achievement category of all injection division production the value of 83.37 in the Fair category.
\end{abstract}

Keywords: Performance, Employees, The Method Of The Balanced Score Card, Key Performance Indicator

\section{INTRODUCTION}

The many types of production of goods are the spearhead of this company's progress in industrial competition in Indonesia, the variety of types of products and large production capacity makes this company need a large number of employees to balance the variety and production capacity. This large number of employees also creates its own problems, one of the problems is employee performance appraisal, employee performance appraisal in this company is only centered on the highest supervisor's consideration in one section.

One of them is the injection division production machine operator whose performance is assessed by the injection division production machine supervisor, while the production machine supervisor is assessed by the injection division production division. The consideration of employee performance appraisal is carried out only through a kind of questionnaire that contains questions about employee performance which are left to be filled in accordance with the wishes of the superior. The employee assessment is also not a routine assessment, but the assessment is only carried out when preparing for the end of the year when preparing for a salary increase or if there is a certain event such as termination of employment with the company.

Developments in this company are the result of good employee performance in all fields within the company, because if there is a part of a company whose performance is bad, it will have a big impact on the company. Performance is the 


\section{Tibuana}

\section{Journal of applied Industrial Engineering-University of PGRI AdiBuana}

DOI : https://doi.org/10.36456/tibuana.4.02.4029.131-139

p-ISSN 2622-2027

$e$-ISSN 2622-2035

result of work in quality and quantity devoted by employees in carrying out work in accordance with the responsibilities assigned to them. Performance is the result of the implementation of a job, both physical and non-physical. Where every job in carrying out its duties as contained in the job description or position, needs to get an assessment after a certain middle of time (Mangkunegara, 2011). Performance is a work achieved by a person in carrying out the tasks assigned to him,(Hasibuan, 2007).

The performance of employees in a company must be assessed correctly because if the assessment method is not correct, the performance of an employee cannot be determined whether the employee is classified as good or not. According to Hasibuan (2003), employees are people who devote services from their thoughts and energy and get compensation whose amount has been determined before working. According to Subri (2002), employees are the total population in a country of productive age who produce goods or services when there is a demand to use their labor, and if they are willing to participate in these activities.

In research conducted at PT Alam Jaya Primanusa researchers used the Balanced Scorecard method. According to Kaplan and Norton (1992) the Balanced Scorecard is a concept of management thinking which was introduced as a development of the concept of performance measurement that measures performance within the company. The Balanced Scorecard consists of two words, namely:

- Scorecard is a card that is used to record a person's performance score which will be used to compare with the actual performance results.

- Balanced, namely to show that the performance of personnel or employees is calculated or assessed in a balanced manner and is viewed from two aspects, namely: financial and non-financial, short-term and long-term, and internal and external.

Meanwhile, according to Tunggal (2001) the Balanced Scorecard is a method used to inform the company's strategy to managers throughout the company. The Balanced Scorecard is a collection of measurement results from employee performance which is the implementation of the company's vision and mission that supports the company's strategy in part or as a whole.

Determination and weighting of Key Performance Indicators is done first which will later be calculated on the Balanced Scorecard method. Key Performance Indicator according to Parmenter (2007) defines as a set of calculations that are created focused on the aspects of organizational or company performance that are most important for the success of the organization or company in current and future conditions. Meanwhile, according to Warren (2011), Key Performance Indicator is how an organization or company executes its strategic vision which is measured in a certain way. The strategic vision in question refers to how the organization's strategy is interactively integrated into the overall organizational strategy.

The use of this method is not without basis and consideration, researchers consider the use of this method by studying previous studies that also discussed the same problem, namely how to assess employee performance. The researcher aims with the results of the Key Performance Indicators (KPI) which are then applied to the Balanced Scorecard (BSC) method. The results of employee performance can be assessed more accurately and in accordance with the required conditions. One similar study conducted by Ariani, Millatul Ulya and Abdul Aziz Jakfar with the title Determination and Weighting of Key Performance Indicators (KPI) as a Tool for Measuring Supply Chain Performance of Mozzarella Cheese Production in $\mathrm{Cv}$. Brawijaya Dairy Industry (Ariani et al, 2017). With one of the research results, the criteria measured in the planning section are as follows: accuracy of raw material estimates (fresh milk), level of raw material inventory in Mitra Bhakti Makmur Cooperative and internal relations with employees. 


\section{Tibuana}

\section{Journal of applied Industrial Engineering-University of PGRI AdiBuana}

DOI : https://doi.org/10.36456/tibuana.4.02.4029.131-139

Another similar study was also conducted by Nashrullah Setiawan and Andang Farmansyah with the title Key Performance Indicator Design for Service Industry Performance Measurement Based on Organizational Culture using the BSCAHP Method (Setiawan \& Farmansyah, 2016). With the results of the research, the criteria measured in the financial section are as follows: increasing profits, increasing debt repayment capabilities and optimizing asset use.

Another similar study was also conducted by Erika Ributari Nugrahayu and Endang Dwi Retnasari with the research title Application of the Balanced Scorecard Method as a benchmark for measuring company performance (Nugrahayu \& Retnasari, 2015). Through this research, the results of the company's performance are good, this is evidenced by the four assessment perspectives applied to measure the performance of PT Glory Indonesia Abadi: the financial perspective of PT Glory Indonesia Abadi as measured by the ratio of profit margin, Return on Investment (ROI) and cost efficiency. shows fluctuating numbers.

Another similar study was also conducted by Yuli Kurnia Firdausia with the title Managerial Performance research with the Balanced Scorecard Method (Firdausia, 2015). With the results of the research, overall hospital performance is good if measured through 4 perspectives, namely customers, finance, internal business as well as learning and growth which the end result is good value.

In order for the discussion in this study to have clear directions and objectives, it is necessary to define the problem, namely research was carried out on all employees of the injection division and took company data in May 2018. The purpose of this study was to determine the correct and accurate method of measuring employee performance, knowing what criteria affect the assessment of employees of the injection division and knowing how to determine the performance of employees who excel.

\section{METHOD}

p-ISSN 2622-2027

$e$-ISSN 2622-2035

The data collection method used in this study is to make direct observations at the company that is the object of research. The data collection techniques used are:

\section{Documentation}

Company documentation, namely by collecting data that has been documented by the company relating to performance measurement.

2. Observation

Observation of all Job Descriptions (JD) in each section to determine the important points that will be selected as Key Performance Indicators (KPI) which will be mapped on the Balanced Score card (BSC) method.

In this study, data processing was carried out using the Balanced Score Card (BSC) method for mapping a balanced Key Performance Indicator (KPI) assessment. The steps taken are as follows:

1. Determination of Key Performance Indicators (KPI).

Determination of Key Performance Indicators (KPI) is determined according to the JD of each employee.

2. Determination of weighting of Key Performance Indicators (KPI)

Determination of value weighting on each Key Performance Indicator (KPI) in accordance with the needs and targets of the company.

3. Mapping Key Performance Indicators (KPI)

The mapping of each Key Performance Indicator (KPI) on the Balanced Scorecard (BSC) is ordered according to the amount of weight that has been agreed upon.

4. Calculation of the final value

The final score calculation is calculated based on the actual value multiplied by the weight of the assessment for each Key Performance Indicator (KPI) on the Balanced Scorecard (BSC).

5. Determination of employee performance categories

The final value is given the minimum and maximum value limits for each category of 


\section{Tibuana}

Journal of applied Industrial Engineering-University of PGRI AdiBuana

DOI : https://doi.org/10.36456/tibuana.4.02.4029.131-139

p-ISSN 2622-2027

$e$-ISSN 2622-2035

assessment, for the classification of employee categories.

\section{RESULT}

From the process of collecting data and observing in the field as well as with managerial parties at PT Alam Jaya Primanusa, Key Performance Indicators (KPIs) have been set along with the method of calculating values and weighting as follows:

- Production Result KPI: The calculation of the production KPI is obtained from the actual production results divided by the production target results multiplied by $100 \%$, the production target is obtained from the effective hours of the machine or employee in one multiplied by the target of each product.

- Material Usage Efficiency KPI: The calculation of the production KPI is obtained from the Bill of Material (BOM) target for the use of production materials divided by the actual use of production materials multiplied by $100 \%$, the production Bill of Material (BOM) target is obtained from the effective hours of the machine or employee in one multiplied with the target of each product.

- Internal Complaints KPI: Calculation of the KPI for internal complaints will get a value of 100 if there are no complaints in 1 month, if you get 1 complaint the value will be 50 , if you get 2 complaints then the value will be 0 .

- External Complaint KPI: Calculation of the KPI for external complaints will get a value of 100 if there are no complaints in 1 month, if you get 1 complaint the value will be 50 , if you get 2 complaints then the value will be 0 .

- Attendance KPI: Calculation of the KPI for internal complaints gets a value of 100 if there are no absences (skipping) from work in 1 month, if you get 1 time absent from work the score becomes 50 , if you get 2 times absent from work, the score becomes 0 .

a. Key Performance Indicator (KPI) for Material Operator

- Production yield : $40 \%$

- Internal Complaint : $30 \%$

- Attendance : $30 \%$

b. Key Performance Indicator (KPI) for Machine Operators

- Production yield $50 \%$

- Efficiency of material usage : $30 \%$

- Attendance $20 \%$

c. Key Performance Indicator (KPI) for Machine Selector

- Production yield $50 \%$

- Internal complaints $15 \%$

- External complaints $15 \%$

- Attendance $20 \%$

d. Key Performance Indicator (KPI) for the Packer section

- Production yield : 50\%

- External complaints : $30 \%$

- Attendance : $20 \%$

After an agreement regarding the determination and weighting of the value of each Key Performance Indicator (KPI) in each section, all production data is processed using Microsoft Excel to facilitate data collection and calculation. After data processing is complete, the following results are obtained: 


\section{Tibuana}

Journal of applied Industrial Engineering-University of PGRI AdiBuana

DOI : https://doi.org/10.36456/tibuana.4.02.4029.131-139

p-ISSN 2622-2027

Table 1. KPI Mapping With Weighting The Value Of The Material Part On The BSC

\begin{tabular}{clcccccccc} 
No & Operator & Result & $\begin{array}{c}\text { Komp } \\
\text {. Int }\end{array}$ & attendance & Result & $\begin{array}{c}\text { Komp. } \\
\text { Int }\end{array}$ & attendance & Result \\
\hline 1 & Yusuf a. & 82 & 50 & 100 & $40 \%$ & $30 \%$ & $30 \%$ & 77.87 \\
2 & M. Ikhsan & 78 & 0 & 100 & $40 \%$ & $30 \%$ & $30 \%$ & 61.22 \\
3 & Toni s. & 84 & 50 & 50 & $40 \%$ & $30 \%$ & $30 \%$ & 63.42 \\
4 & Ana n. & 82 & 50 & 100 & $40 \%$ & $30 \%$ & $30 \%$ & 77.87 \\
5 & Istianah & 82 & 50 & 100 & $40 \%$ & $30 \%$ & $30 \%$ & 77.87 \\
\hline
\end{tabular}

Table 2. KPI Mapping With Operator Share Weighting On BSC

\begin{tabular}{rlcccccccc}
\hline No & \multicolumn{1}{c}{ Operator } & Result & $\begin{array}{c}\text { Effi } \\
\text { cien } \\
\text { cy }\end{array}$ & $\begin{array}{c}\text { attend } \\
\text { ance }\end{array}$ & Result & efficiency & attendance & Result \\
\hline 1 & SetiyaWahyudi & 85 & 88 & 50 & $50 \%$ & $30 \%$ & $20 \%$ & 79.06 \\
2 & HeniChurnia & 87 & 93 & 50 & $50 \%$ & $30 \%$ & $20 \%$ & 81.05 \\
3 & Ariadi Tri S. & 87 & 91 & 100 & $50 \%$ & $30 \%$ & $20 \%$ & 90.60 \\
4 & Ari Widodo & 86 & 94 & 100 & $50 \%$ & $30 \%$ & $20 \%$ & 91.35 \\
\hline
\end{tabular}

Table 3. KPI Mapping By Weighting The Value Of The Selector Section On The BSC

\begin{tabular}{|c|c|c|c|c|c|c|c|c|c|c|}
\hline No & Selector & Result & $\begin{array}{l}\text { Komp. } \\
\text { Int. }\end{array}$ & $\begin{array}{l}\text { Komp } \\
\text {. Eks. }\end{array}$ & $\begin{array}{l}\text { Atten } \\
\text { dance }\end{array}$ & Result & $\begin{array}{c}\text { Komp } \\
\text {. Int }\end{array}$ & $\begin{array}{c}\text { Komp. } \\
\text { Eks }\end{array}$ & $\begin{array}{l}\text { Atten } \\
\text { dace }\end{array}$ & Result \\
\hline 1 & April & 89.05 & 100 & 100 & 100 & $50 \%$ & $15 \%$ & $15 \%$ & $20 \%$ & 94.52 \\
\hline 2 & Bimbing & 88.04 & 50 & 100 & 100 & $50 \%$ & $15 \%$ & $15 \%$ & $20 \%$ & 86.52 \\
\hline 3 & Binti & 80.37 & 50 & 100 & 100 & $50 \%$ & $15 \%$ & $15 \%$ & $20 \%$ & 82.69 \\
\hline 4 & Churotin & 91.49 & 100 & 100 & 100 & $50 \%$ & $15 \%$ & $15 \%$ & $20 \%$ & 95.75 \\
\hline 5 & DwiS. & 94.28 & 100 & 100 & 100 & $50 \%$ & $15 \%$ & $15 \%$ & $20 \%$ & 97.14 \\
\hline 6 & Ida R. & 73.94 & 100 & 100 & 100 & $50 \%$ & $15 \%$ & $15 \%$ & $20 \%$ & 86.97 \\
\hline 7 & Khoridatus & 94.40 & 100 & 100 & 100 & $50 \%$ & $15 \%$ & $15 \%$ & $20 \%$ & 97.20 \\
\hline 8 & Kiromim & 85.88 & 100 & 100 & 100 & $50 \%$ & $15 \%$ & $15 \%$ & $20 \%$ & 92.94 \\
\hline 9 & Musrifah & 79.78 & 100 & 100 & 100 & $50 \%$ & $15 \%$ & $15 \%$ & $20 \%$ & 89.89 \\
\hline 10 & NurR. & 85.46 & 100 & 100 & 100 & $50 \%$ & $15 \%$ & $15 \%$ & $20 \%$ & 92.73 \\
\hline 11 & Nurul & 84.23 & 50 & 100 & 100 & $50 \%$ & $15 \%$ & $15 \%$ & $20 \%$ & 84.62 \\
\hline 12 & Rahayu & 85.56 & 100 & 100 & 100 & $50 \%$ & $15 \%$ & $15 \%$ & $20 \%$ & 92.78 \\
\hline 13 & Rina & 89.60 & 50 & 100 & 100 & $50 \%$ & $15 \%$ & $15 \%$ & $20 \%$ & 87.30 \\
\hline 14 & Rinda & 81.68 & 0 & 100 & 100 & $50 \%$ & $15 \%$ & $15 \%$ & $20 \%$ & 75.84 \\
\hline 15 & Riyana & 83.32 & 50 & 100 & 100 & $50 \%$ & $15 \%$ & $15 \%$ & $20 \%$ & 84.16 \\
\hline 16 & Siti J. & 89.44 & 100 & 100 & 100 & $50 \%$ & $15 \%$ & $15 \%$ & $20 \%$ & 94.72 \\
\hline 17 & Siti M. & 81.78 & 50 & 100 & 100 & $50 \%$ & $15 \%$ & $15 \%$ & $20 \%$ & 83.39 \\
\hline 18 & Sri W. & 90.85 & 100 & 100 & 100 & $50 \%$ & $15 \%$ & $15 \%$ & $20 \%$ & 95.42 \\
\hline 19 & Susilowati.A & 73.13 & 100 & 100 & 100 & $50 \%$ & $15 \%$ & $15 \%$ & $20 \%$ & 86.56 \\
\hline 20 & Susilowati.B & 92.25 & 100 & 100 & 100 & $50 \%$ & $15 \%$ & $15 \%$ & $20 \%$ & 96.12 \\
\hline 21 & Taliya & 96.44 & 100 & 100 & 100 & $50 \%$ & $15 \%$ & $15 \%$ & $20 \%$ & 98.22 \\
\hline 22 & Turofah & 75.42 & 50 & 100 & 100 & $50 \%$ & $15 \%$ & $15 \%$ & $20 \%$ & 80.21 \\
\hline 23 & Yeni & 87.85 & 100 & 100 & 100 & $50 \%$ & $15 \%$ & $15 \%$ & $20 \%$ & 93.93 \\
\hline 24 & Yuli & 85.53 & 50 & 100 & 100 & $50 \%$ & $15 \%$ & $15 \%$ & $20 \%$ & 85.27 \\
\hline
\end{tabular}




\section{Tibuana}

Journal of applied Industrial Engineering-University of PGRI AdiBuana

DOI : https://doi.org/10.36456/tibuana.4.02.4029.131-139

Table 4. KPI Mapping By Weighting The Value Of The Packer Section On The BSC

\begin{tabular}{llccccccc} 
No & Packer & Result & $\begin{array}{c}\text { Komp. } \\
\text { Eks. }\end{array}$ & $\begin{array}{c}\text { Atten } \\
\text { danc } \\
\mathrm{e}\end{array}$ & Result & $\begin{array}{c}\text { Komp. } \\
\text { Eks }\end{array}$ & $\begin{array}{c}\text { Attend } \\
\text { ance }\end{array}$ & Score \\
\hline 1 & Suningsih & 92.03 & 100 & 100 & $50 \%$ & $30 \%$ & $20 \%$ & 96.02 \\
2 & Novi P. & 93.05 & 100 & 100 & $50 \%$ & $30 \%$ & $20 \%$ & 96.53 \\
3 & SitiA. & 90.95 & 100 & 100 & $50 \%$ & $30 \%$ & $20 \%$ & 95.48 \\
4 & Sumarmi & 90.24 & 100 & 100 & $50 \%$ & $30 \%$ & $20 \%$ & 95.12 \\
5 & Fatimah & 88.89 & 100 & 100 & $50 \%$ & $30 \%$ & $20 \%$ & 94.45 \\
6 & AyunS. & 87.78 & 100 & 100 & $50 \%$ & $30 \%$ & $20 \%$ & 93.89 \\
7 & Solikah & 86.95 & 100 & 100 & $50 \%$ & $30 \%$ & $20 \%$ & 93.47 \\
8 & Istikomariyah & 89.82 & 100 & 100 & $50 \%$ & $30 \%$ & $20 \%$ & 94.91 \\
\hline
\end{tabular}

From the recap of the calculation of the data, it can be determined the category of each employee from each production division of the injection division by classifying a certain distance range at the final value. In a certain distance range, the category of employee value classification can be determined starting from the smallest value to the largest value. The classification of these categories will determine the category of employees whose performance is good or bad. The value category for this research has been determined in 3 categories: Good (85-100), Fair (70-84) and Poor (0-69), so that the data obtained are as follows :

Table 5. Division employee achievement category

\begin{tabular}{rlcc}
\hline No & Operator & Score & Category \\
\hline 1 & Yusuf A. & 77.87 & FAIR \\
2 & M. Ikhsan & 61.22 & POOR \\
3 & Toni S. & 63.42 & POOR \\
4 & Ana N. & 77.87 & FAIR \\
5 & Istianah & 77.87 & FAIR \\
\hline
\end{tabular}

Table 6. Operator division employee achievement category

\begin{tabular}{rlcc}
\hline No & \multicolumn{1}{c}{ Operator } & Score & Category \\
\hline 1 & SetiyaWahyudi & 79.06 & FAIR \\
2 & HeniChurnia & 81.05 & FAIR \\
3 & Ariadi Tri S. & 90.60 & GOOD \\
4 & Ari Widodo & 91.35 & GOOD \\
\hline
\end{tabular}




\section{Tibuana}

Journal of applied Industrial Engineering-University of PGRI AdiBuana

DOI : https://doi.org/10.36456/tibuana.4.02.4029.131-139

Table 7. Selector division employee achievement category

\begin{tabular}{rlrc} 
No & \multicolumn{1}{c}{ Selector } & Score & Category \\
\hline 1 & April & 94.52 & GOOD \\
2 & Bimbing & 86.52 & GOOD \\
3 & Binti & 82.69 & FAIR \\
4 & Churotin & 95.75 & GOOD \\
5 & DwiS. & 97.14 & GOOD \\
6 & Ida R. & 86.97 & GOOD \\
7 & Khoridatus & 97.20 & GOOD \\
8 & Kiromim & 92.94 & GOOD \\
9 & Musrifah & 89.89 & GOOD \\
10 & NurR. & 92.73 & GOOD \\
11 & Nurul & 84.62 & FAIR \\
12 & Rahayu & 92.78 & GOOD \\
13 & Rina & 87.30 & GOOD \\
14 & Rinda & 75.84 & FAIR \\
15 & Riyana & 84.16 & FAIR \\
16 & SitiJ. & 94.72 & GOOD \\
17 & SitiM. & 83.39 & FAIR \\
18 & Sri W. & 95.42 & GOOD \\
19 & SusilowatiA. & 86.56 & GOOD \\
20 & SusilowatiB. & 96.12 & GOOD \\
21 & Taliya & 98.22 & GOOD \\
22 & Turofah & 80.21 & FAIR \\
23 & Yeni & 93.93 & GOOD \\
24 & Yuli & 85.27 & GOOD \\
\hline & & &
\end{tabular}

Table 8. Packer division employee achievement category

\begin{tabular}{rlrr} 
No & \multicolumn{1}{|c}{ Packer } & Score & Category \\
\hline 1 & Suningsih & 96.02 & GOOD \\
2 & Novi P. & 96.53 & GOOD \\
3 & SitiA. & 95.48 & GOOD \\
4 & Sumarmi & 95.12 & GOOD \\
5 & Fatimah & 94.45 & GOOD \\
6 & AyunS. & 93.89 & GOOD \\
7 & Solikah & 93.47 & GOOD \\
8 & Istikomariyah & 94.91 & GOOD \\
\hline
\end{tabular}

From the results of these data, the final value for the production of the injection division can be taken by taking the average value of each part (material, operator, selector and packer) and then given a weighting for each part according to the agreement with the company and still using the Balanced Scorecard principle. if all of them are added up, they must not exceed $100 \%$ because the principle on the 


\section{Tibuana}

Journal of applied Industrial Engineering-University of PGRI AdiBuana

DOI : https://doi.org/10.36456/tibuana.4.02.4029.131-139

p-ISSN 2622-2027

Balanced Scorecard is a draw / intact. The table:

$e$-ISSN 2622-2035

agreed weighting will be as in the following

Table 9. Final Score For Injection Division Production

\begin{tabular}{rlrccc}
\hline No & Part Name & Value & Weighting & Final Score & \\
\cline { 1 - 5 } 1 & Material & 71.65 & $30 \%$ & 21.49 & \\
2 & Operator & 85.51 & $35 \%$ & 29.93 & Category \\
3 & Selector & 89.79 & $25 \%$ & 22.45 & \\
4 & Packer & 94.98 & $10 \%$ & 9.50 & \\
\hline & & & & 83.37 & FAIR \\
\hline
\end{tabular}

\section{CONCLUSION}

Determination of the category of employees who perform well or poorly is obtained after the final score calculation is complete, after the final value calculation is complete then the final value is classified according to the range of values in each category that has been determined according to the company's needs, the categories that have been set into 3 categories: Good (85-100), Fair (70-84) and Poor (0-69). The final result of the research conducted at PT Alam Jaya Primanusa in May 2018 the results of the following employee achievement grades and categories: Average material value: 76.65 Fair category, Operator's average value: 85.51 Good category, Average value Selector section average: 89.79 Good category, Packer section average value: 94.98 Good category, Values in each of these sections become the basis for calculations for all injection division production, so conclusions are drawn for the final value and achievement category of all injection division production the value of 83.37 in the Fair category.

\section{REFERENCES}

[1]. Ariani dkk. 2017, Analisis Pembobotan Key Performance Indicator (KPI) dengan Scor Model Menggunakan Metode Analictiycal Process (AHP) Produk Keju Mozzarella di CV Brawijaya Dairy Industry, Junrejo Kota Batu.

[2]. Firdausia, Yuli K. 2015. Kinerja Manajerial dengan Metode Balanced Scorecard.
[3]. Hasibuan, Melayu. 2007. Manajemen Sumber Daya Manusia Edisi Revisi. Jakarta: Bumi Aksara.

[4]. Hasibuan, Melayu. 2003. Manajemen Sumber Daya Manusia. Jakarta: Bumi Aksara.

[5]. Kaplan, R. S. dan Norton, D. P. 1992. The Balanced Scorecard - Measures that Drive Performance. Harvard Business Review.

[6]. Mangkunegara, Anwar Prabu. 2011. Manajemen Sumber Daya Manusia Perusahaan. Bandung : PT. Remaja Rosda Karya.

[7]. Mukhtar, M, N, A. Dan Koesdijati, Titik. 2018. Analisis Postur Kerja Pada Operator Mesin Pond Dengan Menggunakan Metode RULA. Industrialisasi Ekonomi..

[8]. Mukhtar, M, N, A. Dan Muhajir, M, A. 2020. Application Of The Kaizen 5 S Method For The Layout of The Warehouse Section. Journal of Applied Industrial Engineering University Of PGRI AdiBuana. Vol. 3, No. 2, ISSN : $2622-2035$.

[9]. Nugrahayu E. R. dan Retnasari E. D., 2015, Penerapan Metode Balanced Scorecard sebagai Tolok Ukur Pengukuran Kinerja Perusahaan.

[10]. Parmenter, David. 2007. Key Performance Indicators. Jakarta: PT Elex Media Komputindo.

[11]. Setiawan N. \&Farmansyah A., 2016, Desain Key Performance Indicator untuk Pengukuran Kinerja Industri Jasa Berdasarkan Budaya Organisasi dengan Menggunakan Metode BSCAHP (Studi Kasus Hotel Di Semarang). 


\section{Tibuana}

Journal of applied Industrial Engineering-University of PGRI AdiBuana

$p$-ISSN 2622-2027

DOI : https://doi.org/10.36456/tibuana.4.02.4029.131-139

$e$-ISSN 2622-2035

[12]. Tunggal, Amin Widjaja. 2001.

[13]. Warren, Carl S. 2014. Pengantar Economic Value Added / EVA Teori, Soal, dan Kasus. Jakarta: Harvindo. Akuntansi Adaptasi Indonesia. Jakarta: Salemba Empat. 